\title{
HIPERAKTÍV GYERMEK AZ OSZTÁLYBAN
}

Szerzők:

Nagy Lehocky Zsuzsa

Nyitrai Konstantin Filozófus Egyetem

(Szlovákia)

Patai Ilona

Nyitrai Konstantin Filozófus Egyetem

(Szlovákia)

Első szerző e-mail címe: znlehocka@ukf.sk

\section{Lektorok:}

Szabó Edina

Debreceni Egyetem

Szilágyi Barnabás

Debreceni Egyetem

Schréder Veronika

Debreceni Egyetem

Mező Katalin

Debreceni Egyetem

Nagy Lehocky Zsuzsa és Patai Ilona (2015): Hiperaktív gyermek az osztályban. Különleges Bánásmód, I. évf. 2015/2. szám, 49-58. DOI 10.18458/KB.2015.2.49

\begin{abstract}
Absztrakt
Az utóbbi évtizedben fokozott mértékben elötérbe került a hazai és külföldi pedagógiában egyaránt a tanulási és magatartászavarral küzdö gyerekek iskolai nevelésének problémája. A pedagógusok annak ellenére, hogy egyre gyakrabban tanítanak hiperaktív gyermeket, nincsenek rá kellöképpen felkészülve. Részükről a gond abban rejlik, hogy képzésük során nem ismerkedtek meg azokkal a módszerekkel, amelyek segítségével egyénileg fejleszthetöek a nehezen nevelhetö, problematikus személyiségü tanulók. A hiperaktivitás felismerésére és megítélésére a bizonytalanság és a végletek jellemzőek, mert minden túlmozgásos és eleven gyermeket lassan hiperaktívnak titulálnak. A zavarok korai kiszürése pedig lehetövé tenné, hogy a gyermekek időben, megfelelö segítésben részesüljenek.

A következö tanulmány két fö részböl, elméleti, illetve gyakorlati részböl áll. A gyakorlati rész konkrét esettanulmányokat mutat be, segítve ezzel az időbeni felismerést. Három hiperaktív gyermek viselkedésformáit, a rájuk jellemzö tüneteket fejtjük ki bövebben, figyelembe véve a családi és iskolai körülményeket. Felsorakoztatjuk a segítségnyújtás formáit az iskolában, konkrét ötletekkel, tanácsokkal látjuk el a pedagógusokat.
\end{abstract}

Kulcsszavak: hiperaktív, pedagógus, esettanulmány, segítségnyújtás

Diszciplínák: pszichológia, pedagógia

\begin{abstract}
HYPERACTIVE CHILD IN THE CLASS

In the last decade, the issue of school education of children struggling with learning and behavioural disorder has come to the front in domestic as well as foreign pedagogies. The recognition and judgment of hyperactivity is characterised by uncertainty and extremes since increasingly all lively kids with excessive movement are labelled hyperactive. In turn, early detection of the disorders would enable children to get appropriate help.
\end{abstract}


The following study consists of two main parts: a theoretical and a practical one. The practical part introduces concrete case-studies assisting the early detection. The behavioural forms of three hyperactive children and their characteristic symptoms are explicated more broadly taking into consideration the family and school circumstances. It also aligns the forms of assistance and help in schools and gives concrete ideas and advice to teachers.

Keywords: hyperactive, pedagogue, case-study, assistance

Disciplines: psychology, pedagogy

Az iskolakezdés rendkívüli változásokat jelent egy gyermek életében. Nemcsak az otthoni helyzete változik meg valamilyen szinten, hanem az iskola által felállított követelményeknek, előírásoknak, szabályoknak való megfelelés is nehéz feladat elő állítja a gyermeket. A hiperaktív gyerekeknek mindez még nagyobb megpróbáltatást jelent. Hiszen a hiperaktivitás, egy olyan magatartásbeli zavar, melynek során az egyén nem tudja figyelmét tartósan egy dologra összpontosítani és állandó mozgásra van szüksége.

\section{Történeti áttekintés}

A hiperaktív gyerekek egyik legrégebbi és egyúttal legismertebb ábrázolása Heinrich Hoffmann 1845-ben megjelent müve, a Struwwelpeter (Kócos Peti). E müben olvasható rövid tanmesék hőse csupa olyan gyerek, aki valamilyen gondot okoz a szüleinek. Az egyik történet kis hőse - Zappel Philipp - a hiperaktivitásban szenvedő gyerek minden tüneti sajátosságával rendelkezik.

A 20. század elején az angol dr. George Stiel ezeket a gyerekeket „akaratgyengének“ nevezte, a magatartás erkölcsi kontrolljának komoly zavarával, de nem zárta ki az esetleges neurológiai eredetet sem.

1934-ben Kahn és Cohen nevezte ezt a jelenséget „organikus nyugtalanságnak“.

Valamivel később Charles Bradley (1937) leírta a hiperaktív gyerekek tüneteit és bizonyos serkentő szerek adagolásával jó eredményeket ért el, a tünet-együttes pedig a „nyugtalansági szindróma“ elnevezést kapta.

A 60-as években, föleg Amerikában óvatosabban kezdtek bánni azzal a kijelentéssel, miszerint a szülők tehetők felelőssé a tünetek kialakulásáért.

A „minimális cerebrális diszfunkció“ (MCD) elnevezést Berger vezette be 1977-ben, amelyet néhol még ma is használnak.

Később a szindróma az „Attention Deficit Disorder“, ADD elnevezést kapta, amelyet „figyelemzavar tünetegyüttesként“ fordíthatnánk le, később megjelent a figyelemzavar hiperaktivitással együtt (ADHD) megnevezés.

Ehrat és Matmüller-Frick magyar fordításban megjelent müve „A nehezen kezelhető gyermekek (POS)“ pszichoorganikus szindrómáról beszél.

1994-ben a figyelemhiánnyal járó rendellenesség új nevén figyelemhiányos/hiperaktivitászavar tünetegyüttesként jelenik meg.

A szakirodalom tehát sokféle elnevezéssel jelöli a tünetcsoportot: MCD (Minimális agyi diszfunkció), POS (Pszichoorganikus szindróma), HKZ (Hiperkinetikus zavar), ADD (Attention Deficit Disorder, figyelemhiányos rendellenesség), ADHD (Attention Deficit Hyperaktivity Disorder, figyelemhiányos hiperaktivitás rendellenesség), FIMOTA (figyelemzavar - mozgászavar - tanulászavar). 
$\mathrm{Az}$ alaptüneteket három differenciáldiagnosztikai kategóriába rendezik, úgymint figyelemzavar (elkezdett cselekvés abbahagyása, feladatra összpontosítás nehézsége, fokozott elterelhetőség játék során is, stb.), impulzivitás (gondolkodás nélküli cselekvés, szervezetlen feladatvégzés, folyamatos felügyelet igénye, stb.) és hiperaktivitás (extrém expanzív viselkedés, állandó mozgás, nyugtalanság alvás közben is, stb.).

A gyakorisági felmérések adatai meglehetősen ellentmondásosak. Az 1980-as évek vizsgálatai szerint a gyermekkori hiperaktivitás előfordulása 5-10\%. Ugyanakkor az 1990-es évek kutatásai alapján a 3-5\% gyakorisági adat a nemzetközi szinten elfogadott arány. Jelenleg is az ADHD epidemiológiája az iskoláskorú gyermekpopulációban 3-5\%, a fiúk körében jóval gyakrabban fordul elő.

\section{Módszer}

A jelen tanulmány részletesen bemutat három esettanulmányt, melyek alátámasztják azt a feltételezést, hogy a hiperaktív gyermek szülei,t illetve pedagógusait is fel kell készíteni ezen gyerekekkel való különleges bánásmód lehetöségeire.

Az esetelemzések kidolgozása során a következő kutatási módszereket alkalmaztuk:

- Anamnézis (kórelőzmény), amely nem más, mint szóbeli kikérdezés, mellyel az volt a célunk, hogy a vizsgált jelenség előzményeit feltárjuk.

- Interjú, mint kutatási módszer: azért tünt a legcélravezetőbbnek, mert ezzel lehetett a legtöbb, nagyobb mélységeket tükröző információkhoz jutni. Az interjúkat a szülőkkel végeztük el.

- Megfigyeléseink során nyomon követtük a gyermekek viselkedésformáit, megnyilvánulásait (otthon és az iskolában).

- A Conners-féle minősítő skála szülői és pedagógusi változatát alkalmaztuk.

\section{Minta}

A vizsgálatban több gyermek is részt vett, de jelen tanulmányban három esetet mutatunk be részletesen.

\section{Eszközök}

A Conners-féle rövidített tanári minősítő skála (Conners, 1988) a gyermekkori hiperaktivitás vizsgálatánál alkalmazott ismert eljárás. Az iskolai környezetbeli tartós megfigyelésre épülő, 10 viselkedéses jellemzőt tartalmazó szempontsor a figyelemzavarhiperaktivitás szindróma különböző minőségü és súlyosságú tüneteit fejezi ki. A pedagógus mind a 10 viselkedési minősítő kategóriáról eldönti, hogy azok milyen mértékben jellemzőek a kérdezett gyermekre. Meg kell jegyezni, hogy önmagában ez a skála nem alkalmas a diagnózis felállítására, a hivatalos diagnosztizáláshoz több terület szakemberei általi vizsgálat és vélemény szükséges.

A kiválasztott esettanulmányban két fiú és egy kislány történetét mutatjuk be, akik mindannyian diganosztizáltan is sajátos nevelési igényü gyerekek. Alsó tagozatos tanulókat választottunk, hiszen esetükben is a korai segítségnyújtás volt az elsődleges szempont.

\section{Kérdések}

A következő kérdések megválaszolására törekedtünk az esetelemzések elvégzése során. 
1. A terhesség és a szülés lefolyása milyen volt? Jelentkeztek-e komplikációk? (Mivel a szakemberek véleménye szerint a terhesség és a szülés lezajlása nagymértékben befolyásolhatja a hiperaktivitás kialakulását)

2. A szakirodalom által leírt tünetek ténylegesen jellemzik-e a vizsgált gyermeket?

3. Az igazi problémák az iskola szabályokkal irányított rendszerében felerősödtek-e?

4. A hiperaktív gyermekeknél fellépnek-e tanulási zavarok vagy bármilyen problémák, amelyek akadályozzák a tanulásban?

5. Miként viselkedik az ADHD-s gyerek a társas térben, mikro- és makrotársadalmi szinten?

6. Hogyan viszonyulnak a problémához a szülők, az óvoda és az iskola?

\section{Eredmények, esettanulmányok}

Szándékunk szerint esettanulmányaink bemutatása ahhoz járulhat hozzá, hogy a pedagógusok egységes, konkrét képet alkothatnak a hiperaktív gyerekek jellemzőiröl.

\section{1. esettanulmány:}

Zs., 8 éves tanulónál figyelemzavar és hiperaktivitás állapítható meg az eddigi vizsgálatok és tapasztalatok alapján. A Conners-skála alapján végzett kiinduló teszt eredménye 20 pont volt.

A terhesség 42. hetében született, 3500 grammal és 52 cm-rel, császármetszéssel a túlhordás miatt. Az anyuka elmondása alapján már magzatkorban is igen aktívnak bizonyult, az átlagnál többet és jóval intenzívebben mozogott. Félő volt, hogy emiatt koraszülés lép fel.

Csecsemőként nehezen volt nyugtatható, sokat és sokáig sírt, sokszor minden különösebb ok nélkül. Gyakorlatilag éberen aludt. Napközben és éjszaka is a kevés alvásigény volt rá jellemző. 10 hónaposan már ment egyedül. Kisgyermekként örökmozgó, temperamentumos és akaratos, az óvodában elevennek, igazi kis vadócnak tartották. Az óvodai jellemzésében szerepelt, hogy rajzai kusza firkák, túl halványak vagy túl erősek a vonalai, görcsösen fogja a ceruzát, a formák másolása, emberrajzai felismerhetetlenek, elnagyoltak. Nem tud vonal mentén nyírni, általánostól nagyobb ügyetlenség jellemzi a kézmüves tevékenységekben. Ügyetlen az apróbb játéktárgyakkal való játékokban. Figyelme szakaszos.

Nagyon mozgékony. Domináns a csoporton belül. Szokatlanul hangos és impulzív kitörései vannak. Veszélyérzete csekély, gyakran éri és érte őt baleset. Az óvodai séták során hangsúlyosan kellett figyelni rá, gyakran lelépett a járdaszélről, és kifutott az úttestre. Pedagógusainak köszönhetően, nem volt ebből kifolyólag balesete. A játszótéren viszont az impulzivitása miatt mindig adódtak balesetek, leesett a mászókáról, lelépett a mászóka magasabb fokáról, mert nem tudta felmérni a helyzetet, a labdajátékok alatt folyamatosan elesett a saját lábában, a többiekkel sem tudott közremüködni, mert a játékokat idő elött „megunta” és tovább állt. Szülei beíratták egy sportkörre, ahol a rossz mozgáskoordinációs nehézségekre irányuló sporttevékenységekkel és játékokkal foglalkoznak.

Iskolaérettsége nem volt megfelelő, amit a pszichológiai tesztek is igazoltak, ezért egy évet halasztottak. Viselkedését szocializálhatónak minősítették, agresszív jellemvonásokkal. Finommotorikája kezdetleges, figyelme szétszórt, önbizalma normában volt, de kiemelten a részképességzavarok miatt ajánlották az egy év halasztást. Relációkészsége, tartalmi következtetése, íráskoordinációi nem érték el a norma határát.

Nagy benne az újdonság iránti igény, ami az iskolában is megfigyelhető. Ennek következtében gyakran fordul elő, hogy nem tudja végigülni a tanórákat. Különösen akkor, ha számára kevésbé érdekes a tananyag, vagy csak egyszerüen nem sikerül felkelteni és fenntartani az érdeklődését. Ilyenkor unatkozni kezd, és elkezd magának érdekesebb elfoglaltságokat találni. Zavarja a tanórát, beszélget, játszik, olvas, esetleg feláll valamilyen 
mondvacsinált ürüggyel, csak hogy végre mozoghasson egy kicsit. Írása rendezetlen, sok külalaki és helyesírási hibával. Zs. balkezes, ami miatt a szülők nehezebben tudtak segítséget nyújtani az írás elsajátításánál. Olvasása a másodikos osztályos szintnek felel meg, diszlexiás és diszgráfiás jegyekkel. A nyelvtan és olvasás órákat nem szereti. Nehézséget okoz számára egy hosszabb szöveg elolvasása és értelmezése. A szövegértési feladatait akkor teljesíti sikeresen, ha rövidebb a feldolgozandó anyag, egyszerüek a kérdések és számára érdekes a téma.

A figyelemzavar miatt a helyesírása gyenge, gyakori ékezethibával, mivel nem olvassa el maga után a szöveget. A matematikát, a természet- és honismeret órákat kedveli, a feladatokat idő előtt elvégzi, bár gyakran ejt hibákat a figyelmetlensége miatt, pl. hogy nem olvassa végig az elvégzendő feladatokat. Az iskolai munka menetét a gyakori beszólásaival és türelmetlenségével megzavarja. Osztálytársai nehezen viselik, hogy mindenbe beleszól és elsőként füz megjegyzést. Tanító nénije ismerve terhelhetőségét és érdeklődését mindig készít önálló feladatokat a tanórákra. Ezeket az önálló feladatokat gyorsan megcsinálja. Általában gyorsabban dolgozik, mint a többiek, ami további problémák forrása, hiszen ha végzett a feladattal és még várni kell a többiekre, unatkozni kezd, és biztosan talál magának elfoglaltságot. A feladatok megoldásának minősége nagyban függ attól, hogy milyen témát kap, hangsúlyosan tekintettel kell lenni sajátos igényeire. Lehetőséget kell biztosítani számára a mozgást tanóra közben, tehát ő szokta letörölni a táblát, segíteni, felakasztani a térképet, kiosztani a dolgozatokat vagy a feladatlapokat. Terhelni kell őt, hogy ne legyen ideje unatkozni. Az óvodában is ö terített, osztotta ki a lapokat, segített megvetni az ágyakat.

A testnevelés órákon nagyon aktív, nincs kiemelkedő sportteljesítménye, sem érdeklődési köre, csupán szeret mindenben részt venni. Sportkörre és futballra jár heti 1-1 alkalommal, nem jobb és gyorsabb a többieknél, csak állandóan mozgásban kell lennie. Hipermobilitása a szülők elmondása szerint sokszor eredményezi a térdei, lábfeje és bokái erős fájdalmát a nap végén, vagy éjszaka.

Nem viseli jól a bezártságot és a kötött rendszert. A napköziben gyakran feláll, sétál a teremben, többször kikéredzkedik a mosdóba, hogy a folyosón futhasson egyet. Átlagnál gyorsabban fejezi be a házi feladatait. Játék közben szintén megfigyelhetőek a hiperaktivitásra utaló jelek: a kirakós, logikai játékokat, kifestőket nem részesíti előnyben. A mozgást igénylő játékok kötik le, de nem jó csapatjátékos, nem viseli el, ha valaki lassúbb vagy jobb teljesítményre képes, mint ő.

Sok esetben haragos, akaratos és makacs, együttműködésre nem hajlandó. A család elmondása szerint folyamatos konfliktusforrás, hogy nem viseli el öccse „lassúságát”, megfontoltságát és hogy nem partnere a kedvenc játékaiban. Nehezen tud együttmüködni másokkal, látszólag nem törődik a másik érzéseivel, hajlamos a basáskodásra. Mindig ő akar a vezér lenni - mondják az osztálytársai és öccse is. Nem feltétlen az a célja, hogy irányítsa a játékot, hanem nem tudja elviselni, ha nem történik azonnal az, ami eszébe jutott. Emiatt is az iskolában a többi gyerek kiközösíti.

A családi közös étkezések alatt sem bír folyamatosan egy helyben maradni, ami megfigyelhetö az iskolai étkezdében is. A terítésnél a legaktívabb, elsőként végez az evéssel, nem várja meg, míg a többiek befejezik, ilyenkor szórakoztatja a többieket, asztal alá mászik.

Gyakori dühkitörései miatt, pszichológiai és pszichiátriai kivizsgálások sora után, a szakemberek centedrin típusú nyugtatók használatát javasolták, mert a hagyományos nyugtatóktól még inkább impulzívabbá vált.

2. esettanulmány:

S. tünetei igen változatosak, mégis jól körülírhatók. A Conners-skálán 25 pontot ért el. Érdekes, hogy 10 és fél hónaposan már futkározott, egyedül viszont csak 3 évesen tanult meg enni és inni. Kerékpárjáról csak elsős korára vették le a pótkereket, mert figyelmetlensége 
miatt állandóan balesete volt. Észlelése ugrándozó, a feladatokat elsőre nem érti meg, nem képes folyamatosan odafigyelni. Mindez problémát okoz többek között a matematika tanulásánál, főleg a szöveges feladatok megoldásánál. Az egyszerübb matematikai feladatokkal még viszonylag gond nélkül megbirkózik, de szöveges feladatoknál nem érti az állítások közti összefüggéseket. Geometriából az egyszerübb tér és síkalakzatok szerkesztésénél egyfajta térészlelési zavar figyelhető meg nála. Képtelen sorrendiséget felállítani, nemcsak a feladatokban nem tudja ezeket követni, hanem mindennapi tevékenységében sem tudja, hogy mi a fontosabb. Képtelen az idejét hasznosan és megfontoltan beosztani, ezért sokszor lemarad a többiektől. Önálló tanulásra nem képes, folyamatos felügyeletet kíván, nemcsak tanulási zavara miatt, hanem viselkedési zavar miatt is. Gyakran mondják a szülei, hogy "mindent megígér, de semmit nem tart be", mindig halogatja a leckét azért, hogy kibújjon a feladat alól, vagy sokáig ül a könyv mellett, mégsem jut előbbre.

Óvodás kora óta észlelhető volt hirtelen temperamentuma, hamar nyugtalanná vált. Nem viselte el a kudarcot semmilyen formában. Öntörvényü, gyakran alkudozott, makacs és akaratos. A játékszabályokat gyakran megszegte, ami számtalanszor komoly konfliktusokhoz vezetett. Barátai nincsenek, mindenki elpártolt tőle impulzív természete miatt. A játszótéren tönkretette mások játékait, direkt módon bosszantotta a többieket. Az óvodában nehezen birkózott meg a finommotorikát igénylő feladatokkal. Nehezen szocializálható.

Az iskolaérettségi vizsgálaton intellektuálisan érettnek véleményezték, megjegyezték, hogy szabálytartása, feladattudata gyengébb, szociálisan kissé éretlen. Képességei nem térnek el jelentősen az átlag gyerekekétől az iskolában, de ha nem öt szólítatják fel, vagy nem az ö füzetét nézik meg elöször, indulatossá válik, durcás lesz. Mivel decemberi születésü, egy évvel később kezdte az első évfolyamot. Írni és olvasni gyengébb kimenetellel tanult meg, írásképe rendezetlen, olvasása most harmadik évfolyamban is lassúbb és szaggatottabb az átlagnál.

Képtelen a tanítási órákat nyugton végig ülni, mindent kommentál. Folyton babrál, valamije mindig lepottyan, kidöl, vagy éppen a társa holmiját borítja le. Minden mozdulatát hangosan kommentálja. Az iskola és tanító nénije kezdetben nagyon toleránsnak tünt, jelezték a nehézségeket, de bíztatták a szülőket, hogy majd csak belerázódik az iskolás életbe. Második osztály végén váratlanul érte a családot a gyermekről kapott gyenge bizonyítvány a javaslattal, hogy viselkedése, éretlensége miatt ne menjen felsőbb osztályba. A szülök kérésére azonban folytatta tanulmányait. A helyzet nem változott, sőt, a problémák súlyosbodtak, nyíltan megtagadta a tanulást, állandóan zavarta a tanítást, provokálta a tanító és nevelő nénijét. A harag és a düh háttérét nem értették, míg a szülők gyermekpszichiáterhez vitték, megtörtént a kivizsgálás, a figyelemzavar-hiperaktivitás igazolódott. Kognitív viselkedésterápiában részesül (Ayres terápia).

\section{3. esettanulmány:}

K. elsős kislány, akinek súlyos beilleszkedési zavarait hiperaktivitása okozza. A Conners skálán 29 pontot ért el.

A terhesség átlagosnak mondható volt, két alkalommal mértek magasabb vérnyomást, ettől eltekintve minden norma szerint folyt. A születést követően a dolgok viszont megváltoztak, a család élete teljesen felbolydult. K. rendkívül nyugtalan csecsemő volt, anyja szinte 2 évig nem aludt, állandóan sírt, rosszul evett. Anyukája egy idő után már nem is tudta megnyugtatni. Úgy érezte, nem jó anyja a kislányának, talán nem szereti őt a gyermeke. Viszonylag korán, 9 és fél hónaposan elindult egyedül. Az oviban csak két óráig lehetett a csoportban kezelhetetlen agresszivitása, nyugtalansága miatt. Az iskolában is hasonló volt a helyzet, emiatt nem járt napközibe. Társai nem szívesen játszanak vele. Gyakran bosszantja a 
gyerekeket, úgy próbál kapcsolatot teremteni, hogy megzavarja őket, pl. az óvodában lerombolta a többiek által épített várat, tornyot, az iskolában összefirkálja mások füzeteit, elveszi a tízóraijukat.

Gyakorlatilag csak szaladgálva közlekedik. Önállótlan, nem tud elhatározni és végrehajtani. Nem tudja viselkedésének következményeit a jövőre előrevetíteni. Ugyanígy a múltat sem tudja a jelenhez megfelelöen kapcsolni, vagyis úgy tünik, nem tanul az állandóan hangoztatott hibákból. Csak az "itt és most" létezik számára. Nem tud nyugodtan étkezni, nem tud türelmesen ülni az asztalnál. Iskolás kora előtt szinte soha nem tudták hosszabb ideig feladathelyzetben tartani. Mindent hamar megunt, semmi sem kötötte le. Édesanyja otthoni munkát vállalt, mivel egy percre sem hagyhatja magára. Mindenhova felmászik, leugrik.

Rendkívül kíváncsi. Semmivel nem tudja magát lefoglalni, gyakran segítséggel sem. Nem képes egy mesét sem végighallgatni. Mindig mást csinál, mintha nem is hallaná, amit mondanak neki. Tévé mellett sem marad meg hosszabb ideig. Játszása abban merül ki, hogy kiönti játékait a szoba közepére és további elfoglaltság után néz.

Az anyuka félve járt gyermekéért az óvodába, iskolába, hiszen minden alkalommal történt valami galiba. A szülők egy idő után úgy érezték, elveszítették minden kapcsolatukat, elmaradtak a barátaik. Kislányuk felügyeletét már egyetlen nagyszülő sem vállalta, miután mindig adódtak balesetek. Ezen problémák miatt eléggé elromlottak a családi kapcsolatok, felelősség és bünbakkeresés folyt. Ismerősük ajánlására fordultak szakemberhez. A kivizsgálást követően figyelemzavar-hiperaktivitás mellett súlyos beszédértésbeli zavart állapítottak meg. Gyógyszeres kezelés nem volt szükséges, mert megfelelő gyógypedagógiailogopédiai fejlesztésben részesül heti három alkalommal.

Az iskolát egy év késéssel kezdte, ez idő alatt a speciális pedagógus mellett az anyuka is rengeteget foglalkozott gyermeke fejlesztésével. A szülők képzésben, tréningen vesznek és vettek részt, hozzáállásuk változott, felszabadultabban, határozottabban, pozitívan igyekeznek szabályozni kislányuk viselkedését. Az iskolai feladatok megvitatásában is partnerek, jól tudják kezelni lányuk állapotát és helyzetét. A szülők nem szeretették volna speciális iskolába íratni lányukat, külön kérvényezték lányuk állapotára való tekintettel, hogy átlagos iskolában tanulhasson. Szakpedagógus, szociálpedagógus és pszichológus segítségével hangolták össze a tananyagot számára, hogy ne legyen lemaradása a többiekkel szemben, és hogy a tanítás menete és minősége sem csorbuljon. Közös megegyezéssel a napközis oktatásban nem vesz részt, az adottságaira alapozva oktatják őt otthon szülei. K. fizikailag terhelhetőbb, szellemileg kevésbé. A motorikája sokat fejlődött, bár a házi feladat írása még mindig a legmegosztottabb programok egyike, de jelenleg úgy tünik, meg fog birkózni vele. Jobbkezes. A szótagoló olvasást játékos mozgásos formában tanulják, ezt ügyesen befogadja. Tanító nénijük ötletes mozgásos, dalos játékokat is beépít/ett a tanórákba, hogy ezzel is lehetőséget biztosítson mozgásigénye kielégítésére, ez egyébként normális és elvárt ebben az évfolyamban. A szülők aggódnak, hogy a felsőbb évfolyamokban, mikor már a tananyag mennyisége és az idő rövidsége nem teszi mindezt lehetővé, mi lesz lányukkal.

A pedagógus szándékos szófogadatlanságnak tartja viselkedését és ennek visszajelzésére az adott tantárgyból elégtelen érdemjegyet alkalmaz. A pedagógus eszköztelenségét jól tükrözi a beírások sokasága, fekete pontok. Ennek a módszernek az alkalmazása a hiperaktív gyereknél a teljesítmény teljes visszaesését, a tanulás iránti motiváció elvesztését eredményezi.

\section{Segítségnyújtás az iskolában}

A gyermek otthon biztonságban érzi magát, szülei szeretik és elfogadják őt olyannak, amilyen. Ha viszont bekerül idegen gyerekek közé, és egy idegen felnőtt mondja meg neki, hogy mit csináljon, akkor rendkívül bizonytalanná válik, az ingerek közül nem tud szelektálni, szétesik, magatartása az új helyzetek miatt zilálttá válik. Félelmetes és nyomasztó 
érzés ez számukra. A hiperaktív gyerekek állandó és még alaposabb, átgondoltabb felkészülést igényelnek a tanároktól, igazságot, határozottságot, türelmet és sok-sok humort kívánnak.

A következőkben összefoglalunk néhány olyan tanácsot, mely segítheti a munkát egy olyan osztályban, melyben hiperaktív gyermek is jelen van.

\section{Hová ültessük az osztályban a gyerekeket?}

Legjobb az első padba ültetni, középre, mert így kevéssé vonják el figyelmét a különböző dolgok: nem bámészkodik ki az ablakon, az ajtónál ki-bejárnak, hátul ülve minden előtte zajló történésre felfigyelne. Mivel a figyelme nagyon hamar elterelödik, egyszerü és ingerszegény környezetre van szüksége. Sokszor segíthet, ha csendes, szorgalmas, nyugodt társ mellé ültetik.

\section{Magyarázat}

Fontos, hogy mindig teremtsünk vele szemkontaktust. Lassan, érthetően és röviden magyarázzunk. A feladatokat több lépésben adjuk meg, mindig csak egy dolgot kérjünk tőle. Ellenőrizzük, hogy megértette-e a feladatot. Igyekezzünk őt emocionálisan motiválni. Minden új információt próbáljuk meg meghatározott rendszerrel bevezetni, használjunk képeket, diagramokat, ábrákat, szemléltessünk mindent. A figyelmük hosszabb ideig fenntartható, ha minél több érzékszervet kapcsolunk be.

Segítségnyájtás a munka szervezésében

Fontos a tervezés, hogy a gyerek képes legyen lebontani a feladatokat, különben reménytelennek érzi magát és nem tudja elvégezni a feladatot. A padon tanítsuk meg elrendezni a dolgait, semmi felesleges dolog ne maradjon ott, mert eltereli a figyelmét.

\section{Önállóság növelése}

Bevezethetünk saját leckefüzetet, ahova saját maga, padtárs vagy akár tanár is bejelölheti a leckét. Kevesebb házi feladatot adjunk, hiszen nekik minden sokkal több időd vesz igénybe. Praktikus lehet tanulási útmutató tervezése otthonra.

\section{Számonkérés}

Lehetőség szerint ez legyen egyéni számonkérés, legjobb és legkönnyebb ezeknek a gyerekeknek a szóbeli feleltetés. Mivel a kézírásuk gyakorta olvashatatlan, rendetlen, ezért sohase a külalakot értékeljük. Az írás kuszasága, szaggatottsága, a betűk nagyságának egyenetlensége, a nehézkes, görcsös írásmód, a szem és kéz koordinációjának problémáival hozható összefüggésbe. A kézírás minőségére súlyosbítóan hat a csekély figyelmi feszültség is.

\section{Önkontroll erösítése}

A gyerekek maguk is érzik a nyugtalanságot és szeretnének változni, ezért fontos a követelmények pontos megfogalmazása. Megegyezhetünk a gyerekekkel bizonyos szabályokban, mint például:

1. A tanítási órákra rendszeresen készülök.

2. Az osztálytársaimmal és a felnőttekkel kedves és tisztelettudó leszek.

3. Az önálló munkák alatt nem zavarom az osztálytársaimat.

4. Ha valamit szeretnék mondani, előbb jelentkezem.

5. Nem kiabálok, mindig nyugodtan és higgadtan beszélek.

6. Odafigyelek az órán. 
Környezete legyen rendezett, de rugalmas. Fontos, hogy pontos szabályokat építsünk ki, de úgy, hogy amellett elegendő mozgástere, szabadsága maradjon, ne érezze magát korlátozva. A szabályok legyenek határozottak, következetesek, kiszámíthatóak és egyértelmüek. A gyereknek tudnia kell, hogy tettei milyen következményekkel járnak, esetleges szabálysértés esetén. A szabályokon ne változtassunk, csak a gyerek fejlődésének megfelelően. Inkább kevesebb, határozott szabály legyen, mint sok, amit nem tart be.

Megbeszélhetünk saját, egyéni szabályokat is a gyerekkel. Ha bizonyos idő után ezeket nem szegi meg, jutalmazzuk meg érte. Segítsünk felismerni saját érzéseiket és megérteni mások érzéseit. Meg kell tanítani őket az önkontrollra. A feszültség levezetésére nagyon alkalmasak a légzőgyakorlatok, pl. „minden mély belégzéskor és kilégzéskor elszáll belőlem a feszültség". Ha nagyon ingerültnek látjuk a gyermeket, simogatással érdemes megnyugtatni és rövid, világos utasítást adni, pl. „úgy látom, szükséged van egy kis nyugalomra, nyugodtan menj hátra a pihenő sarokba és nézegess egy könyvet”. A tanítónak éreztetni kell a gyerekkel, hogy nem akarja ellenségként kezelni. Minél barátságosabb a viselkedésünk, sok-sok humort használva, annál nagyobb biztonságban érzi magát a gyerek, és jobban tudjuk a tanulásra motiválni. Ha ez sikerül, ezek a gyerekek talán még nagyobb szárnyat kapnak, mint társaik.

\section{Szervezetlen időbeosztás}

Nagyon rosszul viselik a gyerekek, ha valami elöre megbeszélt dolog változik, pl. esik az eső és nem mehetünk ki az udvarra, ilyenkor valami teret kell biztosítani, mozgási lehetőséget.

\section{Jutalom - büntetés}

Amikor sikerül változnia, bármilyen kis mértékben, azt azonnal meg kell erösíteni. Minden sikeres reakciót meg kell dicsérni, pl. „Tetszik nekem, milyen szépen jelentkeztél és csendesen vársz. Nagyon örülök, hogy sikerült megnyugodnod és készen vagy újra rám figyelni”. A hiperaktív gyerekeknél csak a jutalmazással érhetünk el hatást. Dicséret során az értékeléseinkbe mindig foglaljuk bele, hogy mi az, amit jónak látunk. Sokszor nincsenek tisztában azzal, hogy milyen az a jó viselkedés, szükségszerü, hogy konkrétan leszögezzük, mit is várunk el tőle. Ha rossz viselkedés felé tart a gyerek, minél hamarabb meg kell fékezni.

Nem szabad tehát megfeledkezni a jutalmazásról és a büntetésről. Csak az azonnali jutalmazás, ill. büntetés hatásos a hiperaktív gyerekeknél. Az ígéretekkel, fenyegetésekkel az ő esetükben nem megyünk semmire. Dorgálás esetén egyszer közöljük, hogy mi a büntetés, mert ha ismételjük magunkat, akkor a gyerek végül maga dönti el, hogy hányadszorra óhajt szót fogadni. Ha így nem érjük el célunkat, a következménynek azonnal kell történnie, különben nincs értelme. A büntetés nagyon nehéz a hiperaktív gyerekeknél, mivel nem úgy hat rájuk, mint az átlagos gyerekekre. Talán a leghatékonyabb, ha olyan tevékenységtől vonjuk meg őket, ami fontos számukra. Jutalmazni szintén azonnal kell, nem ígérgetni, mivel fontos számukra a sikerélmény, hogy tudják, jót cselekedtek, és ügyesek voltak. Az értékelés minden esetben a tetteikre vonatkozzon, ne a személyiségükre.

\section{Szabad mozgások beiktatása}

A hiperaktív gyerekeknek sokkal nagyobb a mozgásigényük, mint az átlagos társaiknak, ezért fontos mindig lehetőséget adni, ahol kiélhetik fokozott aktivitásukat. A mozgásos feladatok megvalósíthatóak az egész osztállyal, de szólhatnak csak neki is. Keressünk valami ürügyet, hogy elhagyja az osztálytermet, pl. küldjük őt el krétáért, töröltessük le vele a táblát stb.

Ezeknek a gyerekeknek a nevelését az ő sajátosságaikhoz kell alakítani, szeretik a mozgást, a teret, a változatosságot, az új dolgokat, ezért törekedni kell, az ilyen környezet létrehozására. 
Sokat segít, ha konkrét időbeosztásuk van, tehát mindig tájékoztassuk őket, hogy mikor mi fog történni. A feladatok nem szabad, hogy meghaladják képességeiket. Fontos a türelem, a megértés, és legfőképpen az odafigyelés, mert biztos, hogy azoknál a gyerekeknél, akik megkapják a kellö törődést, segítséget, csökkenthetők a negatív reakciók, ezáltal is könnyítve beilleszkedésüket.

\section{Zárógondolatok}

Tom Hartman „A figyelemzavar-szindróma másfajta megközelítése” címü könyvében úgy jellemzi őket, mint „vadászt a földmüvesek társadalmában (Neuhaus, 1997). A hiperaktív gyerek, vagyis a „vadász” mindig a környezetét fürkészi, amivel a figyelmének elterelhetőségét magyarázhatjuk. A vadász rugalmas, bevetésre kész, kedveli a kockázatot, amit tekinthetünk szervezetlenségnek, impulzivitásnak és a következmények figyelmen kívül hagyásának. Az „itt és most”-ban él, amit felfoghatunk türelmetlenségnek. A sztereotip módon rendszerességgel visszatérő dolgok untatják őt. Új ötletekre és lelkesedésre van szüksége, emiatt tartják álmodozónak. A lényegre tér, nem teketóriázik a szociális kommunikációval. Ezt pedig, mint a szociális érintkezési formák ismeretének hiányát róják fel neki.

A jó adottságok kihasználásával gyakran kiemelkedő eredményeket érnek el a társadalomban. Fantáziagazdagság, hajlékonyság, állandó érdeklődés, szokatlan asszociációs lépések, szokatlan ötletek, megfelelő motiváció esetén lenyügöző kitartás, ezek azok a tényezők, amelyek hozzásegítik őket a csúcsteljesítményhez. A saját érdeklödési köreiken belül és tehetségükhöz mérten többé-kevésbé mindegyikük „szenzációs”.

\section{Irodalom}

Conners, C. K. (1988). Conners' teacher's questionnaire. North Tonawanda, NY.: MultiHealth Systems Inch.

Franz, S. (1998). A hiperaktív gyerek. Budapest: Trivium Kiadó.

Gordon, T. (1994). Tanitsd gyermeked önfegyelemre. Budapest: Studium Effektive.

Goetz, M. és Uhlíková, P. (2010). ADHD Porucha pozornosti s hyperaktivitou. Praha: Galén s.r.o.

Jones, M. (2001). Hiperaktív gyermekek. Budapest: Édesvíz Kiadó,

Munden, A. \& Arcelus, J. (2006). Poruchy pozornosti a hyperaktivita. Praha: Portál.

Neuhaus, C. (1999). Hiper-és hipoaktivitás, figyelemzavar. Budapest: Kairosz kiadó.

Ranschburg J. (1998). Pszichológiai rendellenességek gyermekkorban. Budapest: Nemzeti Tankönyvkiadó.

Pokorná, V. (2001). Teória a náprava vývojových porúch učení a chovaní. Praha: Portál s.r.o.

Salló K. és Tóth J. (1995). Problémás a gyermek. Részképességzavarok kialakulása, felismerése, kezelése. Budapest: Littera Nova. 